UDC 343.98

DOI 10.31733/2078-3566-2019-5-194-197

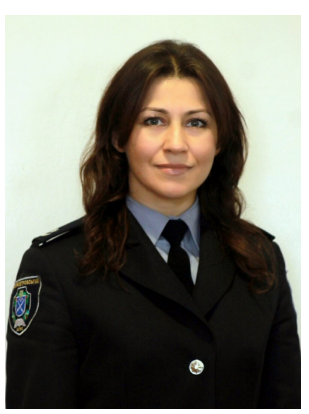

Hanna BIDNIAK ${ }^{\circledR}$

Ph.D

(Dnipropetrovsk State University

of Internal Affairs)

\title{
ON THE CONSERVATION OF THE TRACE PICTURE ON THE CLOTHES OF THE CORPSE DURING ITS EXAMINATION
}

ГанНа БідНЯК. ДО ПИТАННЯ ЗБЕРЕЖЕННЯ СЛІДОВОЇ КАРТИНИ НА ОДЯЗІ ТРУПА ПІД ЧАС ЙОГО ОГЛЯДУ. Досліджено питання щодо виявлення слідів злочину під час огляду ушкоджень одягу трупа на місці події, проаналізовано думки провідних науковців 3 цього приводу. Акцентовано увагу на тому, що одяг перший сприймає дію ушкоджую чого фактору (тупого чи гострого знаряддя, кулі, високої температури й ін.) і тим самим змінюе картину ушкодження на тілі потерпілого. Надані пропозиції щодо огляду одягу трупа, його вилучення та пакування 3 метою збереження слідів для подальшого експертного дослідження. Зазначені особливості слідів біологічних речовин на одязі трупа: крові, сперми, сечі, слини, кала тощо. Їх вид, форма, напрямок, розмір, колір, розташування, ступінь просочування ними тканини дозволяє зробити відповідні висновки (на наявність статевого акту; асфіксію; про тривале перебування тіла в певному положенні тощо). Розглянено питання щодо вогнепальних ушкоджень на одязі трупа, особливу увага приділена пороховим зернам та їх часткам. Надані рекомендації їх фіксації та дослідженні поверхні навколо вхідних отворів та у випадку виявлення порохових відкладень. Визначені помилки, які допускають особи під час огляду трупа та його одягу, серед яких розповсюджені: знятий після огляду одяг 3 ушкодженнями знову надягають на труп, одяг оглядають безпосередньо на тілі трупа, при цьому не знімаючи його загалом.

Зазначене неминуче призводить до втрати важливих деталей, забруднення одягу сторонніми речовинами, не пов'язаними з подією злочину, що може зумовити експертну помилку при подальшому огляді трупа в секційній залі. Доведена зміна слідової картини при порушенні послідовності огляду трупа та його одягу. легко руйнуються під час механічного впливу сліди протекторів шин автомобілів, утворені землистими накладеннями на одязі трупа, через те, що частини, які утворюють ці сліди, обсипаються.

Ключові слова: огляд трупа, огляд одягу трупа, ушкодження одягу трупа, сліди злочину, судово-медичний експерт, слідчий.

Problem statement. The lack of data obtained from the examination of the victim's body may be compounded by a study of his clothing. Clothing, being an artificial cover that protects the human body from the influence of the environment, the first perceives the effect of the damaging factor (blunt or sharp guns, bullets, heat, etc.). Thus, the presence of clothing changes the pattern of damage to the body of the victim, first of all, on his skin, compared with damage on open areas of the body. For example, in a car accident the traces of a car tire tread when moving the victim occur more frequently on their clothing than on the body. In case of a gunshot injuries presence of clothing is crucial to determine the distance of the shot, as clothes can fully apprehend the traces of a close shot and they will be absent on the victim's skin covering.

Naturally, the delaying effect of clothing depends largely on its thickness and density. The more the layers of clothing, the thicker and denser they are, the more pronounced the restraining effect of clothes other things being equal. For example, in the case of damages by rail transport, the presence and severity of the pressure band corpse - the main sign of moving a wheel, depend entirely on the thickness and density of clothing. When a shot with a fractional charge is fired, multilayer dense clothing delays part of the grains and they do not affect the body of the victim. Clothing protects the skin of the body from the effects of high temperature, but in case of fire, it can itself be a source of severe burns to the victim.

Analysis of publications that started solving this problem demonstrate that certain injuries on the body of the victim were investigated by the following scientists: M.F. Krivosh-

\footnotetext{
(C) Bidniak H., 2019

ORCID iD: https://orcid.org/ 0000-0002-0515-9761

an.of@ukr.net
} 
apkin, A.F. Lisitsyn, A.A. Lopatiev, M.M. Tagayev, M.I. Pyrogov, however, some aspects of this issue require further clarification.

The article's objective is to identify, fix and remove traces of crime on the body of a corpse during its examination.

Basic content. The investigator conducts the examination of the corpse, as well as its clothing at the scene, with the obligatory participation of a forensic expert as a specialist. Although it is believed that the investigator directly conducts the examination, his function is to draw up a report. Thus, during a survey of practitioners from an investigative units, about $86 \%$ agreed with this fact and $12 \%$ said that the specialist had an auxiliary role. Also, $78 \%$ of respondents draw up a separate protocol for examination of a corpse, $22 \%$ consider it to be part of the general protocol for examining the scene of an accident.

After describing the position of a corpse in relation to certain objects in the protocol of examination, the type, style, state of clothing, presence or absence of individual elements, breaks, layers, its correspondence to the size of the victim, etc. are recorded. Especially focusing on the major pieces of clothing in case of detection of the unknown corpse; identifying how tightly a tie and belt are tied, the presence of valuable jewelry. Then the corpse is turned over, the clothes are examined from the opposite side, including the presence of extraneous microobjects, the contents of the pockets are examined, and all elements of the clothing are removed in turn. In addition, they also record the conformity of the upper and lower elements of clothing, its smell, the degree of humidity, localization, the size and color of the spots, the degree of impregnation of the fabric, the presence of tags about the place of manufacture. The protocol notes any clutter in clothing. When clothes are lifted, crumpled, dislodged, it can indicate a fight (self-defense), death movements of the wounded, movement of the corpse. If the body is dragged along the ground, horizontal folds of clothing are formed, soiled on the outside and completely clean in folds. The presence of clothing that does not correspond to the growth of the corpse, a sharp difference in the quality of outerwear and underwear is also noted in the protocol. The above may indicate certain facts, such as ownership of another person's clothing.

It is also necessary to record the presence on the clothing of traces of biological substances: blood, semen, urine, saliva, feces, etc., because their appearance, shape, direction, size, color, location, the degree of impregnation of their tissue allows to draw appropriate conclusions. Traces of semen may indicate sexual intercourse; excretion of feces, urine characteristic of asphyxia; the location and direction of the blood traces may indicate the position of the body causing damage; the strong blood leakage of individual pieces of clothing and the considerable length of such streams indicate a long stay of the body in a certain position. Contamination of the victim's clothing with certain materials, the presence of certain odors sometimes indicates the professional identity of its owner. If certain parts of the clothing are removed and located close to the corpse, they are also carefully examined as this may allow one to determine individual circumstances of the event, for example, when committing suicide with the use of a single-footed shotgun, it may be removed for the purpose of pushing a trigger with a finger.

The conditions under which examination of the corpse and its clothing at the scene usually does not allow to reveal all the details of the damage. Therefore, the task of the forensic expert is to find out in advance about the location and nature of the lesions, as well as to properly remove the damaged clothing to send it for detailed laboratory examination.

Before removing clothes from the corpse, it is necessary to match damage of clothes with damage on the body and the direction of the fibers in damaged parts on clothes. At the same time, the examination of the articles of clothing is carried out in the order it was worn on the corpse. Measures are taken to prevent the loss of important material evidence: bullets and their particles, grains, bone fragments, fragments of glass, etc. First of all it is important for gunshot injuries in case these items can be found around both inlet and outlet openings and are usually mostly on clothes with tight, thick and particularly multilayer materials. Fragments of glass can sometimes be found in car injuries.

Shards of the shell and the core of the bullet may be detected in the area of the inlet openings. The latter are formed by the defeat of some special-purpose bullets, as well as by the defeat of ordinary bullets after the previous obstacle has overcome them, which leads to their deformation and tearing into pieces.

Fragments of the shell and core of the bullet can be detected in the area of the inlet of the gunshot openings. The latter are formed by the defeat of some special-purpose bullets, as well as by the defeat of ordinary bullets after the previous obstacle has overcome them, which leads to their deformation and tearing into pieces. Such fragments can be located both on the 
surface of the clothing around the inlet and immersed in its structure, and in the case of damage to multilayered clothing - to be located in its inner layers. When inspecting clothes, all fragments of the bullet should be removed, as they can also become separate physical evidence, the size and location of the center of the main inlet of all damage from individual fragments should be described.

The procedure for detecting and removing specified objects shall be recorded by the investigator in the descriptive part of the scene examination report relating to the examination of the corpse. In order to prevent the loss of the fragments, it is advisable to move the corpse to suitable tarpaulins or other suitable objects (stretchers, sheets, blankets) before examination. The same items are used when transporting a corpse to a autopsy room, protecting it from foreign contamination.

It should be noted that in order for the objects found to have the status of evidence, it is important to properly record them. The protocol should include the following information:

1) name of the articles of clothing available on the corpse, indicating their color;

2) state of clothing on the corpse (unbuttoned, etc.);

3 ) presence of contaminants or secretions of the person and their location;

4) presence of damage [2].

Among the common mistakes often made by the persons, who perfom examination are the following: first, the damaged clothing, which is taken after examination, is put on the corpse again. Secondly, the clothes are examined directly on the body of the corpse, without removing it altogether. This inevitably leads to the loss of important parts, contamination of clothing by outsiders unrelated to the event of the crime, etc., which may lead to expert error when further examination of the corpse in the autopsy room.

In the context of this issue, opinions of K.I. Tatiev and I.V. Skopin regarding the transportation of a naked corpse, which will completely change the picture in the area of damage looks doubtful. The opinion of K.M. Panteleyev that when transporting a dressed corpse it will be subjected to significant changes in damage to the corpse's clothing, and when transporting the corpse without clothing - they will be preserved on the clothes in their original form, provided that they are properly packed looks correct. At the same time, to prevent damage to the corpse, the body may be wrapped in sheets after removal of clothing [3].

Additionally, if the clothes are not removed from the corpse until its research in the laboratory, it may be subjected to numerous mechanical influences, namely during a dynamic stage of examination of the corpse at the scene; as a result of the collision surface of clothes with the walls of the car body during transport; when transferring a corpse to a morgue and undressing it before forensic examination. For example, it is easy to break during the mechanical impact of car tire treads formed by earthy overlays on the corpse's clothing, because the parts that make up these tracks crumble. Traces of mapping that are of great value in a variety of examinations, as a result of manipulations with the corpse, may be lost entirely or partially (becoming ф smear-marks).

When considering fire damage to corpse clothing, particular attention should be paid to powder grains and their particles. Only at the scene does the forensic expert see the full picture of their location around the inlet. Most of the powder is held loosely on clothes and is easily lost (crumbling), which leads to a change in the original appearance of the area of the inlet.

In the absence of reliable methods of preventing the fall of powder grains and their particles from the surface of the clothing when inspected at the scene, it is necessary to carefully examine the surface around the inlets and, in the case of powder deposits, measure the diameter of such deposits and take a picture of the overall appearance of the surface around the inlet.

In this case, it is advisable to remove several grains of powder if they are not firmly attached to the surface of the clothing. Such removal of powder residues is accordingly reflected by the investigator in the protocol of the scene examination, and the extracted grains of the powder are sent for laboratory examination together with items of clothing. At the same time, the soot deposits from the shot are held more firmly on the clothing than the remains of the powder grains. Only smoke, which looks like a layer of loose overlays, can usually be subjected to partial change (lubrication). At the same time, the diameter of the soot sediment, its color, the nature of the edges on the corpse's clothing must be reflected in the examination report. Such an assessment of the damage to the corpse's clothing, in conjunction with other data, may help with reconstruction of the crime scene.

Conclusion. Thus, as a conclusion, it can be noted that a qualified examination of the corpse's clothing at the scene of their detection can provide an important data for clarifying the 
circumstances of the event, the mechanism of the crime. Despite the radically dissenting opinions of both scientists and practitioners, using the general rule of dealing with footprints, we consider it expedient to completely remove the corpse's clothing from the scene as an object carrier for the maximum preservation of the crime traces.

\section{References:}

1. Кримінальний процесуальний кодекс України : Закон України «Про внесення змін до деяких законодавчих актів України у зв'язку з прийняттям Кримінального процесуального кодексу України». Харків : Одіссей, 2012. 360 с.

2. Пантелєєв К. М., Лускатов О. В. Медико-криміналістична експертиза при розслідуванні злочинів, пов'язаних з тілесними ушкодженнями чи смертю особи: Навч. посібник ; заг. ред. C.I. Мінченка. Дніпропетровськ : Дніпроп. держ. ун-т внутр. справ; 2015. 351 с.

3. Судово-медична експертиза у кримінальних справах: Навч.-практ. посібник / В.В. Войченко, В.Д. Мішалов, К.М. Пантелєєв, А.Г. Шиян. 2-е вид., доп. Дніпропетровськ: Дніпроп. держ ун-т внутр справ, 2010. 344 с.

4. Тагаєв М.М. Судова медицина: підручник за заг. ред. проф. О.М. Бандурки. Харків: Факт, 2003. 1253 с.

5. Макаренко Є.І., Негодченко О.В., Тертишник В.М. Огляд місця події: Навч. посібник. Дніпропетровськ : Дніпроп. юрид. ін-т МВС України, 2001. 156 с.

Received to editorial office 04.12.2019

1. Kryminal'nyy protsesual'nyy kodeks Ukrayiny [The Criminal Procedural Code of Ukraine] : Zakon Ukrayiny «Pro vnesennya zmin do deyakykh zakonodavchykh aktiv Ukrayiny u zv"yazku z pryynyattyam Kryminal'noho protsesual'noho kodeksu Ukrayiny». Kharkiv : Odissey, 2012. 360 s. [in Ukr.]

2. Pantelyeyev K. M., Luskatov O. V. Medyko-kryminalistychna ekspertyza pry rozsliduvanni zlochyniv, pov"yazanykh z tilesnymy ushkodzhennyamy chy smertyu osoby [Medical Forensic Examination in Investigation of Crimes Related to Personal Injury or Death] : Navch. posibnyk ; zah. red. S.I. Minchenka. Dnipropetrovs'k : Dniprop. derzh. un-t vnutr. sprav; 2015. 351 s. [in Ukr.]

3. Sudovo-medychna ekspertyza u kryminal'nykh spravakh [Forensic Examination in criminal cases] : Navch.-prakt. posibnyk / V.V. Voychenko, V.D. Mishalov, K.M. Pantelyeyev, A.H. Shyyan. 2-e vyd., dop. i pererob. Dnipropetrovs'k: Dniprop. derzh un-t vnutr sprav, 2010. 344 s. [in Ukr.]

4. Tahayev M.M. Sudova medytsyna [Forensic Medicine]: pidruchnyk za zah. red. prof. O.M. Bandurky. Kharkiv: Fakt, 2003. 1253 s. [in Ukr.]

5. Makarenko YE.I., Nehodchenko O.V., Tertyshnyk V.M. Ohlyad mistsya podiyi [Inspection of the scene]: Navch. posibnyk. Dnipropetrovs'k : Dniprop. yuryd. in-t MVS Ukrayiny, 2001. 156 s. [in Ukr.]

\section{Summary}

The issue of the participation of a forensic expert during of damage clothes of the corpse at the site of its discovery were studied; opinions of leading scientists on this matter were analyzed. The proposals on investigation of corpse's clothes, its extraction and packaging to preserve traces for further expert study are submitted.

Keywords: corpse examination, examination of corpse's clothing, damage of corpse's clothing, traces of crime, forensic expert, investigator. 